\title{
Uroczystość wręczenia Księgi Pamiątkowej ofiarowanej profesor Wandzie Nowakowskiej, Lódź, 7 października 2016 roku
}

W dniu 7 października 2016 r. w nowej siedzibie Katedry Historii Sztuki Uniwersytetu Łódzkiego (UŁ) przy ul. Narutowicza 65 w Łodzi odbyła się uroczystość wręczenia Księgi Pamiatkowej Acta Artis dedykowanej profesor Wandzie Nowakowskiej $^{1}$. Uczestniczyli w niej licznie reprezentowani pracownicy Wydziału Filozoficzno-Historycznego UŁ, członkowie Łódzkiego Towarzystwa Naukowego (ETN) i Stowarzyszenia Historyków Sztuki (SHS), przyjaciele i znajomi Pani Profesor, jej uczniowie, studenci historii sztuki. Niestety sama uhonorowana, złożona choroba, nie mogła wziąć udziału w przygotowanej dla niej uroczystości.

Spotkanie otworzył kierownik Katedry Historii Sztuki, prof. nadzw. dr hab. Piotr Gryglewski, który serdecznie powitał zebranych i przybliżył cel spotkania. Następnie głos zabrała prof. nadzw. dr hab. Eleonora Jedlinnska. Omówiła ona pokrótce koleje losu i karierę naukowa profesor Wandy Nowakowskiej. Zaakcentowała jej zasługi dla utworzenia na Uniwersytecie Łódzkim Zakładu, a następnie Katedry Historii Sztuki, której przez wiele lat Pani Profesor była kierownikiem, jak również dokonania w kształceniu kadry naukowo-dydaktycznej, niezbędnej dla prawidłowego funkcjonowania i rozwoju tego kierunku.

Przypomnijmy zatem, że profesor Wanda Nowakowska urodziła się w Lodzi w 1929 r. W latach 1948-1952 studiowała psychologię, filozofię oraz historię sztuki na Wydziale Filozofii i Wydziale Historycznym UŁ. W roku 1952 uzyskała tytuł magistra w zakresie estetyki na podstawie pracy pt. Teoria wyrazu u Leonarda da Vinci, napisanej pod kierunkiem wybitnego polskiego historyka sztuki o międzynarodowej renomie, profesora Mieczysława Wallisa.

${ }^{1}$ Acta Artis. Studia ofiarowane Profesor Wandzie Nowakowskiej, red. A. Pawłowska, E. Jedlińska, K. Stefański, Łódź 2016, ss. 442. 
Po studiach krótko (1953-1955) pracowała jako asystent w Dziale Oświaty Muzeum Sztuki w Łodzi. Następnie w latach 1956-1960 pełniła funkcje kierownika Działu Popularyzacji Wiedzy i Działu Wydawnictw w ŁTN. Od 1959 r. prowadziła zajęcia dydaktyczne $z$ historii sztuki w Państwowej Wyższej Szkoły Teatralnej i Filmowej w Łodzi oraz w Państwowej Wyższej Szkole Sztuk Plastycznych i Wyższej Szkole Muzycznej w Łodzi. Równocześnie zajmowała się działalnościa naukowa, publikując artykuły i przygotowując dysertację doktorska nt. Koncepcja krytyki artystycznej Stanisława Witkiewicza, również pod kierunkiem profesora M. Wallisa. Rozprawa ta została obroniona w 1965 r. na Wydziale Filozoficzno-Historycznym UŁ. W tym samym roku W. Nowakowska podjęła pracę dydaktyczną i naukową w Katedrze Filozofii UŁ. W 1975 r. przeszła natomiast do nowo utworzonego Zakładu Historii Sztuki, którego pięć lat później została kierownikiem. W roku 1983 otrzymała stopień doktora habilitowanego nauk humanistycznych w zakresie historii sztuki na podstawie rozprawy pt. Narodowa funkcja sztuki $w$ polskiej krytyce artystycznej lat 1863-1890, opublikowanej nakładem Wydawnictwa Uniwersytetu Łódzkiego w 1981 r. Kolokwium habilitacyjne odbyło się na Wydziale Filozoficzno-Historycznym Uniwersytetu Jagiellońskiego. W 1984 r. została powołana na stanowisko docenta w macierzystej uczelni, sześć lat później uzyskała nominację na profesora nadzwyczajnego UŁ, a w 2000 r. tytuł profesora zwyczajnego. Profesor Nowakowska jest autorka sześciu książek oraz blisko 60 artykułów naukowych, popularnonaukowych, katalogów wystaw i tekstów prasowych. Wypromowała ponad 100 prac magisterskich i trzy doktoraty. Za swą działalność naukowa, dydaktyczna i organizacyjna została uhonorowana licznymi odznaczeniami, w tym Złotą Odznaką Uniwersytetu Łódzkiego (1986), Medalem Jubileuszowym 50-lecia Uniwersytetu Łódzkiego (1995), Medalem Komisji Edukacji Narodowej (1997), Medalem Merentibus Stowarzyszenia Historyków Sztuki (2001) i Medalem Univesitatis Lodziensis Merentibus (2014) ${ }^{2}$.

${ }^{2}$ Por. E. Jedlińska, Profesor Wanda Nowakowska, [w:] Profesor Wanda Nowakowska, red. E. Jedlińska, Łódź 2015, s. 11-38, Sylwetki Łódzkich Uczonych, z. 118; e a d e m, Wyróżnienia i nagrody, odznaczenia i członkostwo, [w:] ibidem, s. 67-68; Profesor Wanda Nowakowska, oprac. G. Sztabiński, „Kronika Uniwersytetu Łódzkiego" 2015, nr 5, http://kronika.uni.lodz.pl/numery/pierwsza-nagroda/artykuly/483/profesor-wanda-nowakowska (dostęp: 30 X 2016); O L, Damy na medal, „Gazeta Wyborcza”, 8 X 2001, nr 235, s. 2. 


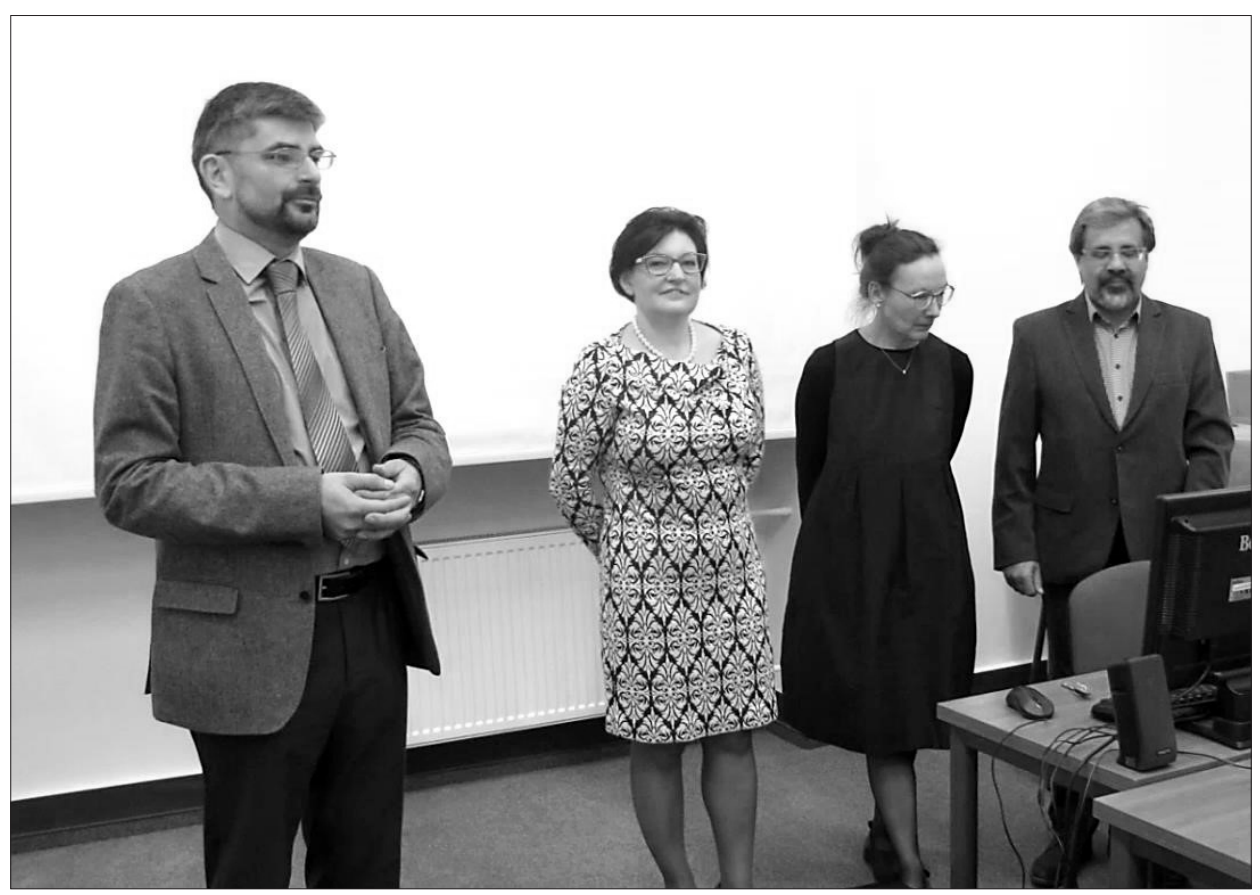

1. Uroczystość wręczenia Księgi Pamiątkowej poświęconej profesor Wandzie Nowakowskiej (od lewej: prof. nadzw. dr hab. Piotr Gryglewski, prof. nadzw. dr hab. Aneta Pawłowska, prof. nadzw. dr hab. Eleonora Jedlińska, prof. dr hab. Krzysztof Stefański), fot. J. Frenkel

Po przedstawieniu życiorysu profesor Wandy Nowakowskiej głos zabrał prof. dr hab. Krzysztof Stefański, który w kilku słowach przybliżył jej działalność organizacyjną. Podkreślił, że jest ona współzałożycielką Łódzkiego Oddziału SHS, powołanego do życia w 1953 r. W ramach aktywności w tej instytucji Pani Profesor wygłaszała liczne odczyty, pełniła funkcję członka Komisji Kwalifikacyjnej, przewodniczacej Sekcji Popularyzacji, Sekcji Naukowej i wiceprezesa. Była też członkiem Zarządu Głównego SHS (1985-1990) i zastępca sekretarza generalnego (1994-1997) w tym Zarządzie. Istotne znaczenie ma także wieloletnia działalność W. Nowakowskiej w ŁTN. Do najważniejszych jej osiagnięć należy zaangażowanie w utworzenie w 1996 r. Wydziału VI - Sztuki i Nauk o Sztuce. Została powołana na jego przewodniczaca i przez dziesięć lat owocnie piastowała tę funkcję. Za zasługi związane $z$ tą działalnością otrzymała tytuł członka honorowego ŁTN (2005) oraz Medal ŁTN (2007). 


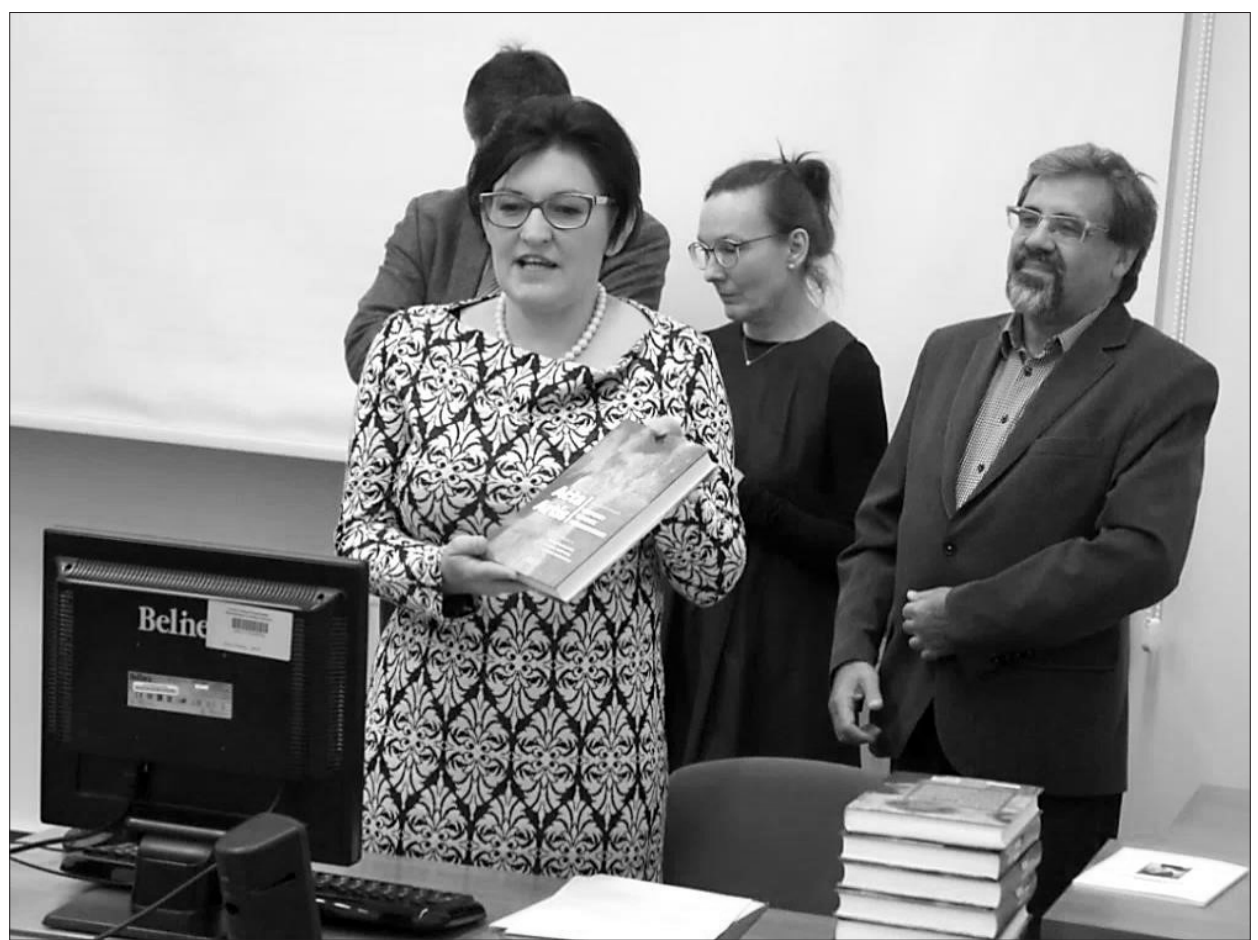

2. Profesor Aneta Pawłowska przemawiajaca w czasie uroczystości, fot. autorka

Jako ostatnia w imieniu komitetu redakcyjnego Acta Artis przemówiła prof. nadzw. dr hab. Aneta Pawłowska. Podziękowała ona autorom tekstów do Księgi Pamiątkowej za owocną współpracę i omówiła jej zawartość. W celu wprowadzenia pewnego porządku metodologicznego oraz pokazania różnych nurtów badawczych istotnych dla W. Nowakowskiej publikacja została podzielona na cztery części. Część pierwsza (Profesor Wanda Nowakowska jako historyk sztuki) jest najbardziej osobista. Znalazły się tu teksty badaczy związanych $z$ ŁTN, współpracowników i wychowanków Pani Profesor. Część druga, nosząca tytuł Teoria, dotyczy rozważań skoncentrowanych na dziele sztuki, znaczeniu filozoficznym oraz jego walorach estetycznych. Zamieszczono tu m.in. ciekawe studium profesor Ilony Skupińskiej-Løvset nad wizerunkiem Afrodyty w sztuce, będace oczywistym nawiązaniem do zainteresowań badawczych W. Nowakowskiej, a także artykuł profesora Grzegorza Sztabińskiego pt. Empatia $w$ sztuce - dawniej i dziś, w którym autor w niezwykle zgrabnym dyskursie wskazuje, jak praktyczna lekcję empatii w odniesieniu do sztuki i człowieka przekazała mu 
Pani Profesor. Część trzecia poświęcona została malarstwu, a ostatnia architekturze. Opublikowano w niej teksty, które odnosza nas zarówno do innych obszarów geograficznych (jak choćby artykuły dr Ewy Kubiak na temat budownictwa w Buenos Aires czy dr. Piotra Sadowskiego o architekturze europejskiej w Malakce), jak i niezbyt odległych lub zgoła bliskich miejsc (np. szkic profesora Lechosława Lameńskiego dotyczący krakowskiego budynku Bazar Polski). $\mathrm{Na}$ zakończenie profesor Pawłowska wyraziła wdzięczność dziekanowi Wydziału Filozoficzno-Historycznego UŁ, prof. dr. hab. Zbigniewowi Anusikowi za udzielone wsparcie finansowe, dr. Tomaszowi Pietrasowi $z$ Instytutu Historii za skład i łamanie książki, jak również Fundacji Uniwersytetu Łódzkiego, która pomogła w zgromadzeniu funduszy niezbędnych do realizacji planowanego przedsięwzięcia.

Ostatnim punktem uroczystości było wręczenie przez komitet redakcyjny pamiątkowego tomu autorom tekstów. Po spotkaniu odbył się tradycyjny poczęstunek, przygotowany przez uzdolniona kulinarnie doktorantkę z Katedry Historii Sztuki. Współpracownikom i uczniom Pani Profesor serdecznie gratulujemy podjętej inicjatywy, a Jej samej życzymy dużo zdrowia, realizacji życiowych pasji oraz wielu jeszcze lat twórczej pracy naukowej. Niech narodzi się kolejna „wieczna Ewa”.

MaEgorzata Karkocha UNIWERSYTET ŁÓDZKI*

\section{Bibliografia}

Acta Artis. Studia ofiarowane Profesor Wandzie Nowakowskiej, red. A. Pawłowska, E. Jedlińska, K. Stefański, Łódź 2016.

Jedlińska E., Profesor Wanda Nowakowska, [w:] Profesor Wanda Nowakowska, red. E. Jedlińska, Łódź 2015, s. 11-38, Sylwetki Łódzkich Uczonych, z. 118.

Jedlińska E., Wyróżnienia i nagrody, odznaczenia i członkostwo, [w:] Profesor Wanda Nowakowska, red. E. Jedlińska, Łódź 2015, s. 67-68, Sylwetki Łódzkich Uczonych, z. 118.

OL, Damy na medal, „Gazeta Wyborcza”, 8 X 2001, nr 235, s. 2.

Profesor Wanda Nowakowska, oprac. G. Sztabiński, „Kronika Uniwersytetu Łódzkiego" 2015, nr 5, http:/ / kronika.uni.lodz.pl/numery/pierwsza-nagroda/artykuly/483/profesor-wanda-nowakowska (dostęp: 30 X 2016).

\footnotetext{
*Wydział Filozoficzno-Historyczny, Instytut Historii, Katedra Historii Nowożytnej.
} 